УдК 349.2

\author{
A. М. Слюсар, I. В. Колосов
}

\title{
ПОНЯТТЯ ПРОЦЕДУРИ В ТРУДОВОМУ ПРАВІ, ЇЇ МІСЦЕ, РОЛЬ ТА ДУАЛІСТИЧНА ПРИРОДА ЯК ЗАПОБЖЖНОГО МЕХАНІЗМУ І ПІДГРУНТЯ ЕФЕКТИВНОГО СУДОВОГО ВИРІШЕННЯ ТРУДОВИХ СПОРІВ
}

Постановка проблеми. Сучасні наукові дослідження в галузі трудового права потребують приділення більшої уваги феномену процедури вирішення трудових спорів, встановлення критеріїв ііі відмежування від процесу. Як зазначає І.Ф. Шелеп, «на сучасному етапі досить важливим $€$ вирішення питання розподілу матеріального і процесуального в трудовому праві».

Однак для трудового права вирішення цього питання досить проблемне. Як зазначав із цього приводу Д.О. Морозов, складність визначення процесуальних явищ у трудовому праві пов'язана з його загальною охоронною спрямованістю [10, с. 4]. Ми підтримуємо цю думку і вважаємо, що вирішенню зазначеної проблеми сприятиме з'ясування співвідношення між процедурою і процесом. Це також дозволить відмежувати процес у правовому значенні від різновидів юридичних процедур трудового права. В.Д. Сорокін вказував на те, що, говорячи про «процес» $\mathrm{i}$ «процедуру», ми маємо справу зі складними і багатогранними явищами, які об'єднують в собі визначені загальні властивості, що поширюються на всі різновидності процесу» [15].

Дійсно, кажучи про процедуру у трудовому праві, ми маємо справу 3 досить поширеним явищем. Серед останніх напрацювань вчених харківської школи права, під загальним керівництвом чл. - кор. НАПрН України О.М. Ярошенка виділяється процедура укладення трудового договору, прийняття на роботу, виплати заробітної плати, атестації працівників, розірвання трудового договору, вирішення індивідуальних та колективних трудових спорів [14, с. 240-243, 255-311, 376, 395, 503-526].

Разом із тим вирішення трудових спорів згідно із чинним законодавством - це не лише результат процедури, але і процесу. Із цього приводу слід зазначити, що такі вчені (вітчизняні та країн СНД), як Беззуб Б.С., Голяк Л.В., Мацко А.С., Кисельов Й.Я., Забрамна О.Ю., Шмельова Н.С., [5; 9, с. 79-14], а серед зарубіжних - D. Esplin, K. Sugeno, Ullmann, 
Bothfeld [3, с. 4-17; 8; 11] та ін. не розрізняють процедури і процесу вирішення трудових спорів, об'єднуючи їх терміном «процедура» («procedure»), або «судова процедура».

Проте процедура в трудовому праві має і свої, притаманні лише ій функціï, а саме: запобіжну та ефектоутворюючу, що не мають відношення до процесу. Судовий процес не запобігає виникненню трудових спорів та не підвищує ефективності їх розв'язання на локальному рівні. Він має свої, особливі захисні завдання, котрі не притаманні процедурам трудового права.

Мета. Отже, завданням пропонованого дослідження є 3'ясування правової природи процедури, іiі місця та ролі у трудовому праві, оцінка іiі як запобіжного механізму та підгрунтя ефективного судового вирішення трудових спорів, а також встановлення критеріїв розмежування термінів «процедура» та «процес» у контексті галузево-правового дослідження.

\section{Виклад основного матеріалу.}

§ 1. Поняття процедури в трудовому праві, iii місце та роль у регулюванні трудових відносин.

За загальним визначенням, процедура - це певна взаємопов'язана послідовність дій, котрі спрямовані на досягнення певного результату. Із цього визначення можна логічно виокремити наступні компоненти: хто може, вчиняє ці дії, з якою метою вони вчиняються, який їх зміст та який бажаний результат.

Відповідаючи на перше питання, слід звернути увагу на суб'єктів трудового права, з огляду на предмет дослідження. Ярошенко О.М. виділяє серед таких суб'єктів основних (працівників та роботодавців) та неосновних (трудові колективи, професійні спілки, органи державної влади - Мінсоцполітики та Кабінет Міністрів України) [14, с. 87-130].

3 точки зору мети та змісту процедури умовно можна поділити на правовстановлюючі (прийняття на роботу, виплата заробітної плати), правозмінюючі (переведення на іншу роботу, накладення дисциплінарного стягнення і т.п.), правоприпиняючі (розірвання трудового договору). Ці процедури мають матеріально-правовий зміст, оскільки спрямовані на досягнення матеріально правового результату. Інакше кажучи, якщо матеріальні норми трудового права закріплюють ті правомочності, якими наділені суб'єкти правовідносин, то процедура встановлює порядок, регламент, алгоритм їх набуття.

Цікаву точку зору із цього приводу демонструє І.Ф. Шелеп у своєму дослідженні під назвою «Загальна характеристика правових процедур трудового права»: «Процедура - один із соціальних регуляторів. Вона відіграє важливу роль не лише в регулюванні поведінки окремих суб'єктів, а й у забезпеченні дотримання принципів права, ефективної реалізації правових норм та захисті прав особи. Адже, як вказував Ю.В. Феофанов, закон без процедури його здійснення призводить до вседозволеності влади, а громадянинові не гарантує захищеності. Відповідно, держава не може стати правовою за наявності винятків із правил та за відсутності процедур [1]. Отже, процедурно-правові приписи - це гарантія правопорядку та законності. 
Первинний зміст терміну «процедура» означає офіційно встановлений порядок дій при обговоренні чогось, здійсненні або оформленні прав [2, с. 772]. У широкому значенні процедура визначається як послідовність актів чи операцій, які мають здійснювати у визначеному порядку за присутності представників влади, громадських організацій чи уповноважених фізичних осіб із метою досягнення виконання того чи іншого акту [3, с. 58]. Поняття «процедура» визначається як порядок, наступність, послідовність у вчиненні відповідних дій для досягнення певного результату; під правовою процедурою розуміється врегульований законом чи іншими нормативно-правовими актами порядок, який складається з послідовних дій. Сутність правової процедури зумовлена характером матеріально-правових відносин, для реалізації яких вона слугує. Особливість ії в тому, що вона застосовується у сфері права [4, с. 185].

В.Н. Протасов також зазначає, що юридична (правова) процедура діє в юридичній сфері, врегульована правовими нормами, структурована правовими відносинами, спрямована на правовий результат [5, с. 3, 7]. Водночас науковець цілком обгрунтовано не обмежує сферу дії процедури лише матеріально-правовими відносинами, зазначаючи, що вона слугує для реалізації правових відносин загалом. При цьому він зазначає, що поняття «правова процедура» привертає увагу через дві обставини: по-перше, через важливість їі соціальної ролі; по-друге, через іï маловивченість, оскільки в юриспруденції добре розроблені галузеві теорії двох видів процесу - цивільного і кримінального, а в загальноправовому плані наявні лише окремі погляди, концепції юридичної процедури, а цілісної процедурно-правової теорії поки що нема.

Для розвитку галузі трудового права і наукової розробки теорії трудового юридичного процесу також важливим $є$ досконале закріплення процедурних вимог, встановлення гарантій реалізації суб’єктивних трудових прав та обов'язків, удосконалення правового механізму їхнього забезпечення. Із цього приводу В.Н. Кудрявцев зазначав, що окремі приписи закону, навіть чітко сформульовані, часто залишаються безрезультатними або використовуються недостатньо ефективно. Одна з причин полягає в тому, що не завжди продуманий порядок застосування закону, надто ускладнена чи взагалі не встановлена процедура [6]. Таким чином, ефективність норм трудового права багато в чому залежить від процедури, причому не тільки в юрисдикційних сферах, тобто не лише при вирішенні правових проблем та спорів про право.

Л.М. Распутіна вважає, що в галузі трудового права суттєвим недоліком сучасного стану трудових відносин є відсутність здебільшого злагодженого механізму реалізації закладених у законодавстві принципів, спеціальних органів і процедур та недостатній рівень юридичної техніки [7, с. 90]. Виокремлені В.Н. Протасовим ознаки юридичної процедури притаманні і правовим процедурам трудового права. До цих ознак, зокрема, належать: орієнтованість на досягнення конкретного результату; внутрішня структурованість суспільними відносинами і наявність у структурі актів поведінки, 
які послідовно змінюють один одного; наявність моделі свого розвитку, попередньо встановленої на нормативному та індивідуальному рівні; службовий характер, який виступає засобом реалізації основного, головного для неї суспільного відношення; ієрархічна побудова; постійна динаміка та розвиток, тобто одна процедурна норма деталізує іншу, одні процедурні відносини забезпечують процес реалізації інших [5, с. 6]. Правові процедури у сфері трудового права досить різноманітні за своїм характером, який визначається специфікою механізму їхної дії і різноманітністю трудових відносин як матеріальних, так і процесуальних» [15].

3 викладеного матеріалу можна вивести певні проміжні висновки:

1) процедурою в трудовому праві є визначений законом порядок вчинення юридично значимих дій, дотримання якого надає ознак впорядкованості та легітимності трудовим відносинам;

2) процедура - це соціальний регулятор, спосіб правового регулювання суспільних відносин, котрий характеризується внутрішньою структурованістю, регламентованістю, ієрархічною побудовою тощо;

3) процедура існує для суб'єктів відповідних правовідносин та має своє поширення та юридичне значення саме для них;

4) процедура може бути спрямована на матеріально-правовий або процесуально-правовий результат.

Таким чином, процедуру в трудовому праві можна визначити як регламентовану законом, соціонормативну регуляторну послідовність вчинення юридично значимих дій суб'єктами трудових правовідносин, що спрямована на їх встановлення, зміну та припинення і має на меті досягнення певного правового результату.

Таке визначення, з нашої точки зору, є більш вдалим, оскільки не торкається питань процесу, відмежування котрого від процедури є значною проблемою для трудового права.

Повертаючись до дослідження І.Ф. Шелеп, у продовження думки, маємо виділити таке: «Підкресливши важливість наявності науково обгрунтованого в трудовому праві поняття «трудова процесуальна процедура», Д.О. Морозов зазначає, що вона репрезентує правовідносини особливого виду. Він також вказав на те, що іхня характерна риса проявляється здебільшого в необхідності детального нормативного регулювання. Сторони трудових відносин, за окремими винятками, наділені правом встановлювати порядок проходження трудової процесуальної процедури» [10, с. 8]. Трудові процесуальні правовідносини мають вторинний, похідний, службовий, підпорядкований характер стосовно тих правовідносин, реалізації яких вони слугують. Як і всі процесуальні відносини, вони є владними та публічними, оскільки виникають внаслідок діяльності, що здійснюється в державних чи суспільних інтересах, і забезпечується охороною держави.

Відповідно до трудових процесуальних процедур належать: розгляд i вирішення спорів (питання підвищення ефективності процедур вирішення трудових конфліктів), процедури реалізації трудо-правової відповідальності (проблеми удосконалення процедур дисциплінарної та матеріальної 
відповідальності); при цьому трудові процесуальні процедури пов'язані з реалізацією трудоправової відповідальності і поділяються на два провадження - дисциплінарне (дисциплінарний процес) та провадження 3 притягнення до матеріальної відповідальності; процесуальні питання вдосконалення процедур контролю та нагляду в сфері праці; процесуальні аспекти самозахисту трудових прав (самозахист може бути двох видів передбачений договором і законом, при цьому не можна заперечувати наявність у роботодавця права на самозахист) [10, с. 8, 18].

Ці процедури є різновидом трудово-правової процедури, хоча визначати їх як правовідносини не цілком обгрунтовано, адже будь-які галузеві правовідносини є суспільними відносинами, що врегульовуються правовими нормами. Юридична (правова) процедура встановлюється з метою врегулювання цих правовідносин, відповідно вона закріплюється в правових приписах і визначає певний порядок дій. Слід відзначити, що за умови закріплення трудових процесуальних процедур з метою врегулювання конфліктних ситуацій, вирішення трудових спорів або відновлення порушеного трудового права зазначені процедури доцільно іменувати трудовими юрисдикційними. Науковці неодноразово підкреслювали, що процедура завжди пов'язана з процесом, режимом, регламентом, протоколом [3, с. 58]. У правовій доктрині домінуючою є позиція, за якою найбільшою мірою матеріальні і процесуальні явища стикаються одне з одним саме у сфері юридичної процедури. Тут вони мають найбільше спільних моментів і тут найскладніше провести між ними лінії розмежування. Тому на сучасному етапі досить важливим є вирішення питання розподілу матеріального і процесуального в трудовому праві. Досліджуючи юридичні процедури в контексті уточнення категоріального апарату процедурної теорії, В.Н. Протасов висловив думку про те, що поняття «процесуальна процедура» i «юридичний процес» відображають одне і те ж явище, але в різних аспектах. Коли йдеться про процесуальну процедуру, то увага акцентується на тих властивостях процесу, які відрізняють його від інших видів правової процедури. Поняття ж «юридичний процес» - загальне для його різновидів: цивільного, кримінального та ін. [3, с. 15].

Науковці також зазначають, що юридичний процес $є$ різновидом юридичної процедури і спрямований на виявлення та реалізацію матеріальних, охоронних правовідносин, які передбачають своєрідність їніх рис (обов'язкову наявність у складі владного суб'єкта; специфіку заходів, що застосовуються; як правило, високий рівень нормативної регламентації та ін.), і основне - особливий механізм зв'язку з матеріально-правовою регулятивною сферою [3, с. 15]. Дозволимо собі не погодитися із зазначеними твердженнями 3 таких міркувань. По-перше, при ототожненні юридичного процесу і будь-якого виду процедури нівелюється функціональне призначення кожного із цих понять. Незважаючи на те, що зв'язки між процедурою і процесом багатоаспектні, ці явища не є рівнозначними. Процес і процедура в трудовому праві співвідносяться між собою як система та елемент. Саме у свої послідовній сукупності правові процедури 
об’єднуються у творенні певного виду юридичного процесу (галузевого процесу), зокрема трудового. Кожен вид юридичного процесу є досконалим і цілісним, оскільки систематизовано об'єднує матеріальні, процесуальні та організаційні правові процедури. Слід зазначити, що найістотнішою відмінністю між процедурою та процесом є зміст діяльності. Так, процедура завжди характеризується функціональним поєднанням операцій, тоді як для процесу може мати місце механічна зміна правовідносин. По-друге, при зведенні поняття «процесу» до «процедури» відбувається обмеження його змісту, при цьому процедура теж втрачає характерні їй ознаки. По-третє, в контексті розгляду «процесу» та «процедури» як синонімічних термінів будь-яку дію (сукупність дій) можна вважати процесом. Однак у такому випадку відбувається підміна понять. Юридичний процес та кожен його галузевий вид має спеціальне правове значення (наділений об'єднуючою функцією щодо процедур, стадій та проваджень), і чим досконалішим він є, тим ефективніша кожна з його складових, які, незважаючи на їхній зміст і функціональну спрямованість, належать процесу.

При дослідженні структури механізму правового регулювання, як зазначив Д.О. Морозов, не завжди чітко окреслюється функція процедурних та процесуальних утворень, їхній характер співвідношення з іншими підсистемами. Представники галузевих наук ототожнюють юридичну процедуру 3 механізмами реалізації інтересів різних суб'єктів права. До такого висновку можна прийти, якщо не враховувати «подвійну» природу правової процедури: з однієї сторони, вона є регламентованим порядком вчинення юридично важливої дії, а з іншої - самою діяльністю, яка забезпечує реалізацію норм права в правовідносинах і відповідає цьому порядку. Лише в першому випадку юридичний процес може бути охарактеризований як певний механізм. Це дозволяє розглядати в структурі механізму правового регулювання трудового права не лише матеріально-правове, а й процедурно-правове регулювання, до якого як складова частина належить механізм трудового процесуального регулювання [10, с. 11]. Для трудово-правової процедури правовідносини, з однієї сторони, виступають як організовувані (процес реалізації яких забезпечується), а з іншої - як організовуючі (ті, які забезпечують). Зазначена В.Н. Протасовим [3, с. 7,3$]$ «висота» ієрархії (тобто кількість деталізуючих один одного процедурних відносин, що залежить від того, в якій мірі повинен бути деталізований процес реалізації основного правовідношення) властива і процедурам в галузі трудового права.

У цілому погоджуючись із запропонованими твердженнями, на наш погляд, не можна сприйняти визначення «трудова процесуальна процедура». Дана калька лише заплутує науковців, оскільки змішує процедуру і процес. Неможливо погодитися і з лише змістовним критерієм їх розмежування, оскільки існує і суб'єктний: суд за своєю правовою природою не є суб'єктом трудового права, але ж вирішує трудові спори за своїм регламентом - процесом. Більш того, судовий процес поширюється не тільки ж на трудові, але і на інші (цивільні, сімейні, земельні) спори, через що його не можна звужувати до змісту терміну «процедура». Не є процес часткою 
процедури, бо існують і процесуальні галузі права. Тому терміни «процедура» та «процес» слід розглядати як рівноправні.

У той же час є і інші органи, котрі вирішують трудові спори i відносяться до суб'єктів трудового права (наприклад, КТС). Отже, дуалістичний характер процедури полягає не тільки в тому, що вона є формою забезпечення прав і самостійною діяльністю, а і в певній трансформації в залежності від суб'єктного складу, чому уваги в пропонованому дослідженні не приділено.

Але $є$ і ще одна ознака дуальності процедури в трудовому праві. 3 одного боку, вона має превентивну (запобіжну) функцію. 3 іншого, іiі дотримання значно полегшує судове вирішення трудового спору, якщо таке в подальшому і стається. Тому детальне вивчення феномену процедури та встановлення критеріїв ії відмінності від процесу неможливе без наукового вивчення зазначених іiі якостей.

§ 2. Дуалістична природа процедури як запобіжного механізму і підгрунтя ефективного судового вирішення трудових спорів.

Насамперед, слід відмітити, що попередні наші дослідження приділяли недостатньо уваги зазначеному питанню [7, с. 127-143]. Поворотним моментом у цьому контексті стала робота під назвою «THE TYPES OF PROCEDURES AND LABOUR DISPUTES' RESOLUTION SYSTEMS: JAPANESE EXPERIENCE AND UKRAINIAN REALITIES», в якій було приділено значну увагу саме видам процедур вирішення трудових спорів та виокремлено невиправдане поєднання термінів «процедура» $\mathrm{i}$ «процес» [4, с.130-134]. У подальшому нами було виокремлено процедурно-процесуальну дилему - явище, котре яскраво виділялося на прикладі ФРН. Так, було встановлено, що «65\% трудовых споров в трудовых судах Германии заканчиваются компромиссом сторон. И это при том, что в случае использования административных процедур (в частности, советов трудящихся), по тем же данным, до суда доходит лишь 35-38\% споров» [6, с. 34-37]. Тобто при виборі між адміністративною процедурою та судовим процесом, зокрема в Німеччині, робітники у $62-65 \%$ обирають процедуру. На частку процесу припадає 35-38\% спорів, але ж і з них шляхом компромісу вирішується $65 \%$. Таким чином, шляхом ухвалення судового рішення вирішується приблизно лише $1 / 6$ частина усіх трудових спорів у ФРН, проте навіть за такого становища існування системи трудової юстиції вважається виправданою.

Частково відповідаючи на питання про причину такого вибору, Esplin на прикладі Великобританії, посилається на дороговизну судового провадження. У своєму дослідженні зазначений автор посилається на високий статистичний показник ефективності альтернативної процедури вирішення трудових спорів (75-86 \%), але при цьому вказує на певні ії недоліки, використовуючи досвід таких країн, як США, Японія, Нова Зеландія, Камбоджа.

Зазначені показники свідчать про функцію процедури як запобіжного механізму судового провадження. Але в деяких країнах процедура на сьо- 
годні є вже інструментом превенції виникненню трудового спору. Із цього приводу не зайвим буде ознайомитися 3 досвідом Італії. Як зазначають M. Weiss, A. Seifert, G. Kronisch, J. Gschwinder, W. Bromwich, «імплеменація норм закону про менеджерів середньої ланки (quadri intermedi) у 1985 році виявила обмеженість цієї норми та іï недостатність у питаннях захисту інтересів виконавчих менеджерів - групи, котра була охоплена змістом поняття «топ-менеджери» (dirigenti). До цього спонукала система представництва топ-менеджерів, що знаходилася під впливом норм корпоративного періоду. Закон про профспілки від 1926 року застерігав від визначення топ-менеджерів як окремої категорії та виділення іх в окрему групу керівників зі складу професійних спілок та федерацій. Концепція корпоративного бізнесу заохочувала створення нової елітарної групи найманих працівників, котрі виконують не лише технічні функції, але грають і певну політичну роль, чим відрізняються від інших найманих працівників. Ця тенденція збереглася і в подальшому. Червнений референдум 1995 року підтвердив представницький статус конфедерацій професійних спілок у частині укладання генеральних угод, що послабило їх роль на місцевому рівні та негативно відобразилося на окремих повноваженнях менеджерів середньої ланки. Це допомагає зрозуміти те, що лише одна сфера економіки - банківська - має окрему угоду для менеджерів середньої ланки. Інша національна угода включає в себе спеціальні повноваження для зазначеної категорії керівників, у той час як окремі угоди прирівнюють менеджерів середньої ланки до «білих комірців» (металургія, машинобудування, хімічна промисловість і т.п.). На теперішній час більшість працівників - членів профспілок об'єднані через секторальні організації (organiszazioni di categoria) в три організації, що склалися історично: Генеральна конфедерація Італії з праці (ГКІП); Генеральна конфедерація профспілок Італії (ГКПІ); Трудовий Союз Італії (ТСІ). Колективні переговори для топ-менеджерів або dirigenti відокремлені від інших працівників. Існує тільки одна колективна угода, що охоплює dirigenti в усіх сферах індустріі, з окремими угодами для інших макросекторів, таких як сільське господарство, комерція, банківська сфера, страхування та публічна служба.

В Італії право на інформування та консультування закріплено для галузевих профспілок на національному рівні та представницьких органів на рівні компанії. Не існує спеціалізованих вимог або процедур для професіоналів чи керівних посад. Вони користуються цими правами нарівні 3 членами тієї організації, що уповноважила їх на представництво. Три найбільші асоціації виконавчих менеджерів запропонували загальний план для організацій професійних спілок щодо пріоритетів колективних переговорів:

- профспілкові переговори та спеціальні переговори другого рівня;

- правила для різної оплати праці та оплати праці, пов'язаної з рівнем виконання робочих обов'язків, визначення робочого часу, його пов'язаності із цілями виробництва;

- встановлення часового проміжку між націальними переговорами та спеціальними переговорами другого рівня; 
- розвиток широкого кола тренінгів та тренінгових можливостей; аудит професійних навичок та кар'єрне планування для загальної кар'єри та оцінки тренінгових можливостей.

У процесі дискусіі, що призвела до секторальних національних угод, пропозиції для виконавчих менеджерів включали в себе quadri та охоплювало:

- тренінги, що закріплювали періодичні, на рівні компанії, огляди потреб та навичок, розвиток процедур і програм і встановлення мінімальної кількості годин для щорічних тренінгів;

- правову допомогу в цивільних чи кримінальних справах в справах, що пов'язані з виконанням роботи, коли quadri обирають собі представника самостійно і він оплачується компанією;

- прозорість у питаннях щодо міжнародного обміну для менеджерів середньої ланки;

- ініціативи щодо встановлення робочого часу та недопущення понаднормової роботи для quadri. Найбільш пізні результати цих угод спостерігаються в хімічній промисловості, де укладено угоди про облік робочого часу з індивідуальним розрахунком понаднормового часу роботи, що періодично переобліковується та не може перевищувати 50\% загального робочого часу або, альтернативно, часу відпочинку та відпусток, навчання чи декретної відпустки.

Наступні пропозиції обліку робочого часу стосувалися наділення представників компанії повноваженнями щодо верифікації того, скільки понаднормового робочого часу витрачається додатково на переговори; національного огляду щодо розвитку навчальної діяльності, обумовленої періодичними оглядами навчальних потреб у компанії і на рівні секторів економіки. Кажучи більш детально, асоціації виконавчих менеджерів Італії запропонували зміни до Закону № 190, відповідно до яких визначаються наступні напрямки реформування:

- переосмислення ролі висококваліфікованих професійних функцій у зв'язку з новими тенденціями в публічних та приватних установах;

- розширення норм, що охоплюють собою публічний сектор економіки;

- захист права на представництво;

- переконання в тому, що закон забезпечений заходами примусу завдяки санкцій там, де цього раніше не було;

- запровадження національного огляду для виконавчих менеджерів із метою здійснення досліджень та вироблення стратегії керівництва так само як і верифікації випадків, коли необхідно звернення по допомогу закону» [12].

Таким чином, можна зробити висновок про те, що наявність специфічних процедур колективних переговорів для керівників середньої та вищої ланки в Італї являє собою доктринальний пласт попередження та вирішення колективних трудових спорів для всіх інших категорій працівників, завдяки складному та напрацьованому механізму договорів та угод, колективних перемовин та консультацій, інформування, тренінгів, професійного 
навчання, періодичних оцінок потреб у професійних навичках, робочого та понаднормового робочого часу, взаємодії професійних спілок, федерацій, конфедерацій та керівників підприємств як на національному, так і на місцевому рівні, що дозволяє більш оперативно реагувати на зміни у виробничій структурі економіки, іï запити та потреби, надає можливість виробити модель правової поведінки для вирішення колективних трудових спорів рядових працівників, які, здебільшого, і є членами цих самих профспілок.

Такі процедури, з нашої точки зору, є не просто запобіжними, але і прогностичними, бо зорієнтовані на подальші зміни в економіці та упередження навіть появі причин для виникнення трудового спору шляхом перемовин, діалогу, безпосереднього вербального контакту. Як тут не згадати слова Дейнеки В.М. у його авторефераті дисертаційного дослідження на тему «Примирні процедури вирішення трудових спорів», виконаного під керівництвом чл.-кор. НАПрН України Чанишевої Г.І.: «Із розвитком соціального діалогу у сфері праці особливої уваги потребують способи мирного врегулювання розбіжностей між сторонами трудових правовідносин. Велике значення для ефективного вирішення трудових спорів мають примирні процедури, де сторонам або спеціально створеним органам надається можливість урегулювати розбіжності, що виникли, шляхом досягнення спільних домовленостей та прийняття узгоджених рішень» [2]. Важко не погодитися з представниками одеської школи права, особливо в контексті дослідженого матеріалу зарубіжних вчених.

Без сумніву, дана функція процедури в трудовому праві є самостійним явищем, котре несумісно з процесом. Із цієї точки зору вбачається некоректним визначати процес як складову частину процедури, бо процес не призначений для попередження конфліктів у майбутньому; його завдання полягає в захисті того права чи законного інтересу, порушення якого вже сталося.

Інша сторона проблеми полягає у функції процедури як підгрунтя ефективного судового вирішення трудового спору. Із цього приводу слід звернути увагу на дослідження R. Crowely щодо діяльності трудових судів Королівства Таїланд, де суд не тільки діє в тісному поєднанні з адміністративними органами - Міністерством праці та Міністерством внутрішніх справ, але і надає правові висновки з приводу застосування ними закону під час їх процедурної діяльності: «Розділ 8 Закону про затвердження процедури для Трудового Суду від 1979 року (далі - Закону) закріплює та розкриває суть поняття «юрисдикція трудового суду». У відповідності до цього розділу правові підстави, що дозволяють судові слухати та вирішувати справу, виходять з наступного: (1) спір полягає в правах чи обов'язках, що витікають з трудової угоди або умов (термінів), що містяться в наказі про прийняття на роботу; (2) спори полягають у правах чи обов'язках відповідно до законів, які пов'язані із Законом про охорону праці чи Законом про трудові відносини; (3) справи повинні розглядатися судом у відповідності до Закону про охорону праці чи Закону про трудові відносини; (4) апеляційні скарги на рішення компетентних органів, пов'язані із законодавством про охорону праці, або на рішення Комітету з трудових відно- 
син чи Міністерства праці; (5) справи виникають із підстав незаконного акту індивідуальної дії, між роботодавцями та найманими працівниками у зв'язку із трудовим спором або виконанням трудових обов'язків відповідно до трудової угоди; (6) трудові спори, в яких Міністерство внутрішніх справ звертається до трудового суду із поданням про вирішення спору у відповідності до Закону про трудові відносини» [10].

У даному випадку суд виступає не як орган, що встановлює фактичні обставини справи, а перевіряє законність і обгрунтованість прийнятих процедурних рішень та дотримання приписів закону щодо порядку вчинення юридично значимих дій у трудових відносинах.

Де ж тоді пролягає грань між процедурою та процесом? У контексті зазначеного вже зрозуміло, що термін «трудова процесуальна процедура» навряд чи є виправданим.

Із цього приводу цікавою є точка зору дослідників групи «johannete RHEEDER incorporated», котрі вивчали питання дисциплінарних слухань у Південно-Африканській Республіці: «According to the Labour Relations Act, section 188 stipulates that a dismissal is unfair if the employer fails to prove that the reason for the dismissal is a fair reason based on the misconduct or incapacity of the employee, or is based on the employer's operational requirements, and that the dismissal was effected in accordance with a fair procedure. Furthermore, any person considering whether or not the reason for dismissal is a fair reason or whether or not the dismissal was effected in accordance with a fair procedure, must take into account any relevant code of good practice issued in terms of the LRA, specifically, schedule 8 . Schedule 8 deals predominantly with the procedural elements of a disciplinary hearing. When an act of misconduct occurs, the employer should conduct an investigation to determine whether there are grounds for disciplinary action and dismissal. This does not need to be a formal enquiry. The employer should then notify the employee of the allegations using a form and language that the employee can reasonably understand. The employee is entitled to a reasonable time (minimum 2 clear working days) to prepare his defense and is entitled to the assistance of a trade union representative or a fellow employee. This constitutes the core rights of an employee when suspected and charged of misconduct. After the enquiry, the employer should communicate the decision taken, and preferably furnish the employee with written notification of that decision. If the employee is dismissed, the employee should be given the reason for dismissal and reminded of any rights to refer the matter to a council with jurisdiction or to the CCMA or to any dispute resolution procedures established in terms of a collective agreement within 30 days. Procedural fairness in general terms refers to a disciplinary hearing that has to be held to afford the employee the opportunity to state his or her defense. This, by no means, requires the employer to hold a "mini court" case. The code does not substitute the employers' own procedures and if the employer has its own disciplinary code of conduct, it should adhere to the principles set out therein. Employers who do not have their own disciplinary rules must adhere to the principles set out in schedule 8 and should be mindful 
of the requirement of "consistent discipline". It should at least ensure that it applies the requirements of schedule 8 in a consistently manner, to all employees suspected of misconduct» [1].

Ми недарма виділили саме фразу "mini court" case, котру можна перекласти або як «мінісудова» справа, або як «квазісудова» справа. Оскільки така справа вирішується примирними органами підприємства або адміністративними інституціями, до неї цілком підходить визначення процедури. Дійсно, до складу примирних органів підприємства входять визначені О.М. Ярошенко неосновні суб'єкти трудових відносин, а адміністративні органи є органами державної влади також відповідають наведеній класифікації.

Що ж тоді припадає на частку так званого «чистого» процесу? Відповідь, на наш погляд, проста: всі відносини із захисту трудових прав, у котрі залучений суд з моменту надходження позовної заяви. До цього часу, навіть на стадії підготовки позову, порядок такого захисту слід вважати процедурою, бо зазначена підготовка пов'язана саме з діями суб'єктів трудових відносин.

3 огляду на зазначене слід дійти висновку про множинність трансформацій феномену «процедура» у трудовому праві, що потребує собою певних узагальнень.

Висновки. Досліджений матеріал дозволяє нам виокремити певні групи трансформацій, котрих зазнає процедура як правове явище під час регулювання трудових відносин.

1. Процедура є регламентованим порядком вчинення юридично важливої дії;.

2. Процедура - це діяльність, яка забезпечує реалізацію норм права в правовідносинах і відповідає цьому порядку.

Наведена подвійність цілком відповідає критерію матеріально-правової процедури в трудовому праві та не викликає сумнівів в іiі справедливості.

1. Процедура є запобіжним механізмом виникнення спору.

2. Процедура $є$ запобіжним інструментом надходження спору на вирішення суду.

3 даної подвійності слідує окремий випадок процедури - запобіжна (превентивна) процедура.

1. Процедура може бути способом адміністративного чи примирного вирішення спору суб'єктами галузевих правовідносин.

2. У зазначеному випадку в разі виникнення судового спору процедура набуває ефектоутворюючої функції, бо зводить задачу суду не до встановлення фактичних обставин справи, а до перевірки законності та обгрунтованості процедурного рішення та дотримання матеріально-правової процедури.

Третя і остання подвійність процедури має ознаки квазіпроцесуальної. У подальшому до вирішення спору залучаються судові органи, котрі діють за специфічним регламентом - процесом.

Отже, підсумовуючи доктринальні надбання вітчизняної та зарубіжної юриспруденції, слід визнати, що:

1) процедура як регламентований порядок юридично важливої дії та діяльність, яка забезпечує реалізацію галузевих норм права в правовід- 
носинах і відповідає цьому порядку, є власне матеріально-правовою процедурою;

2) процедура, котра спрямована на запобігання виникненню спірної ситуаціі (конфлікту) в галузевих правовідносинах, а так само надходженню спору на вирішення суду, є запобіжною (превентивною) і становить собою окремий випадок процедури;

3) процедура, за якою вирішуються спори суб'єктами галузевих правовідносин, а так само яка $є$ підгрунтям подальшого ефективного судового вирішення спору, є квазіпроцесуальною;

4) 3 моменту надходження спору на вирішення суду процедура трансформується у процес.

У наведених правилах (а вірніше, постулатах, оскільки вони витікають 3 фактів, систематичних та емпіричних пояснень), на наш погляд, виражається суть та природа процедурно-процесуального дуалізму, котрий, 3 одного боку, підкреслює єдність процедури і процесу, а 3 іншого - дозволяє визначити критеріï їх нееквівалентності та самостійності, що цілком відповідає діалектичному закону єдності та боротьби протилежностей.

Таким чином, для трудового права наведені постулати процедурно-процесуального дуалізму є способом вирішення тієї невизначеності межі між процедурою та процесом, котра викликає неоднозначні думки науковців. Разом із тим питанням ознак кожної трансформації процедури, їі властивостей та можливих ефектів повинні бути присвячені подальші дослідження, зокрема і в галузі трудового права, з метою вдосконалення форм і способів правового регулювання трудових відносин та підвищення рівня їх ефективності в цілому.

\section{Література}

1. Disciplinary hearings. Fair and Unfair Procedures | South Africa | Labour Law. [Електронний ресурс] - Вебсайт: http://www.jrattorneys [Електронний ресурс]. - Електронні дані. Режим доступу : http://www.jrattorneys.co.za/south-african-labour-law-articles / disciplinaryhearings.html (дата звернення 22.11.2017 року).

2. Дейнека В.М. Примирні процедури вирішення трудових спорів : автореферат на здобуття наук. ступеню к. ю. н. : спец. 12.00.05 - трудове право ; право соціального забезпечення. [Електронний ресурс] - Електронні дані. - Режим доступу : http://dspace.onua.edu.ua/ bitstream/handle/11300 (дата звернення 22.11.2017 року).

3. Employment dispute resolution in Great Britain the case for change an international perspective. David Esplin MSc. Honorary Senior Research Fellow Centre for Research in Employment Studies Employment Research Service University of Hertfordshire Business School Hatfield Herts AL10 9AB. - P. 4-17.

4. Ilya Kolosov. The types of procedures and labour disputes' resolution systems: Japanese experience and Ukrainian realities /I. Kolosov// "Jurnalul juridic national: teorie si practica" Publicatie stiintifico - practica de drept. Fondatori: Instituţia Privată de Onvățămont Institutul de Științe Penale și Criminologie Aplicată Ontreprinderea cu capital străin «Demsta» S.R.L. Chisinau. - Aprilie 2017. № 2 (24), 2017 - P. 130-134.

5. Забрамная Е.Ю., Шмелева Н.С. Обзор систем разрешения трудовых споров, применяемых в развитых странах. Електронний ресурс [Електронні дані]. - Режим доступа : http:/ / www.trudsud.ru/ru/docs/publications (дата звернення 22.11.2017 року).

6. Колосов И. Принцип 6 Конвенции о защите прав человека и основоположных свобод в контексте процедурно - процессуальной дилеммы при разрешении трудовых споров / 
И. Колосов / / International scientific conference "Innovative research of legal regulation of public administration": Conference Proceedings, June 16 - 17, 2017. Lublin. - P. 34-37.

7. Колосов І. Профілактика військових злочинів як засіб подолання злочинності: соціально - трудовий аспект / I. Колосов / / Військові злочини: кримінально - правова, криміналістична та кримінологічна характеристика: колективна монографія / За заг. ред. В.М. Стратонова, Є.Л. Стрельцова. - Херсон : Видавничий дім «Гельветика», 2015. - С. 127-143.

8. Labor Situation in Japan and Its Analysis: General Overview 2013/2014 - P. 121-127. [Електронний ресурс] - Електронні дані. - Режим доступу : http://www.jil.go.jp/english/lsj/ general/2013-2014/4-4.pdf (дата звернення 22.11.2017 року).

9. Порівняльне трудове право: Навч. посіб. / Б.С. Беззуб, Л.В. Голяк, О.М. Кісілевич та ін. - Київ : МАУП, 2005. - С. 79-114.

10. Review of Act on the establishment of and Procedure for Labour Court (1979). -[Електронний ресурс]. - Електронні дані. - Режим доступу : https://www.thailandlawoffice.com/ node/271 (дата звернення 22.11.2017 року).

11. The German Employment Protection Act - How does it work in company practice? - Karen Ullmann / Dr. Silke Bothfeld. WSI-Diskussionspapier Nr. 161 Juni 2008. - [Електронний ресурс] Електронні дані. - Режим доступу : https://www.boeckler.de/pdf/p_wsi_diskp_161_e.pdf (дата звернення 22.11.2017 року).

12. The Position and Function of Executive Staff Members in Italian Labour Law. [Електронний peсурс] - Електронні дані. - Режим доступу : https://moodle.adaptland.it/.../ebook_vol_3_ pag_313.pdf (дата звернення 22.11.2017 року).

13. Slusar A.N., Kolosov I.V. Procedural and processual problems during appearance and resolution of labour disputes in contest of Constitutional Changes on justice / Slusar A.N., Kolosov I.V. / / Процес модернізації системи державного управління: конституційний, адміністративний та фінансовий аспекти: колективна монографія / За заг. ред. д. ю. н., проф. А.С. Нестеренко. Одеса : Видавничий дім «Гельветика», 2017. - С. 479-490.

14. Трудове право: підручник / О.М. Ярошенко, С.М. Прилипко, А.М. Слюсар та ін. ; за заг. ред. О.М. Ярошенка. - 2 - ге вид., переробл. і допов. - Харків : Право, 2017 - 560 с.

15. Шелеп І.Ф. Загальна характеристика правових процедур трудового права / I.Ф. Шелеп. - [Електронні дані]. - Режим доступу : http://vuzlib.com/content/view/2436/115/ (дата звернення 22.11.2017 року).

\section{Ано т а ц і я}

Слюсар А. М., Колосов I. В. Поняття процедури у трудовому праві, іiі місце, роль та дуалістична природа як запобіжного механізму і підгрунтя ефективного судового вирішення трудових спорів. - Стаття.

Стаття присвячена дослідженню феномену процедури у трудовому праві, іï місцю та ролі в регулюванні трудових відносин, а також висвітленню критеріїв розмежування понять «процедура» та «процес».

Ключові слова: процедура, процес, трудове право, процедурно- процесуальний дуалізм, запобіжний механізм.

\section{А н н о т а ци я}

Слюсар $A . H .$, Колосов И. В. Понятие процедуры в трудовом праве, ее место, роль и дуалистическая природа как предохранительного механизма и почвы для эффективного судебного разрешения трудовых споров. - Статья.

Статья посвящена исследованию феномена процедуры в трудовом праве, ее месту и роли в регулировании трудовых отношений, а также освещению критериев размежевания понятий «процедура» и «процесс».

Ключевые слова: процедура, процесс, трудовое право, процедурно-процессуальный дуализм, предохранительный механизм. 
A. М. Слюсар, I. В. Колосов. Поняття процедури в трудовому праві, іiі місце, роль... 157

\section{S u m m a r y}

Slusar A. N., Kolosov I. V. The definition of "procedure" in labour law, its place, role and dual nature as preventive mechanism and background for effectiveness of Court labour disputes resolution. - Article.

This article highlights phenomenon of "procedure" in labour law its place and role in labour relations' regulation and criteria of separation between notions of "procedure" and "process".

Key words: procedure, process, labour law, procedural dualism, preventive mechanism. 